\title{
亞鉛陽極による水門屝防蝕に関する試験
}

中川雅 央**筧 建 莫*

\section{Control of the Corrosion of Dock Gate by Zinc Anodes}

A painted doc'k gate (Approx. $2000 \mathrm{ft}^{2}$ ) was prevented from corrosion by means of installed thirteen zinc anodes of super high grade. The graph and table showing the current out-put and consumption rate of each anole, and a table exhibiting the prote-
Masao Nakagawa \& Takehiko Kakei

ctive result with steel test pieces are presented. It was found that the super high grade zinc anode shows steady current out-put and excellent current efficiency in sea-water.

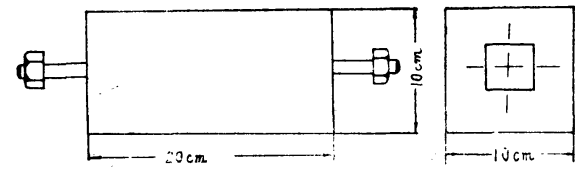

$42 \div$

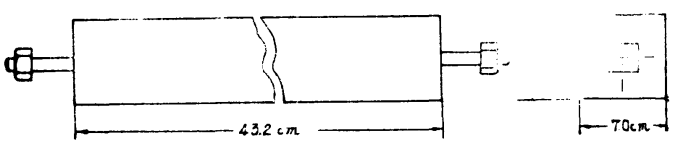

L翌

芽 2 図陽極 の形状

第1表陽極の純度と分類

使用した亞鈆の分析值 $(\%)$

\begin{tabular}{c|c|c|c|c|c}
\hline \hline 成 分 & $\mathrm{Zn}$ & $\mathrm{Pb}$ & $\mathrm{Cd}$ & $\mathrm{Cu}$ & $\mathrm{Fe}$ \\
\hline $\mathrm{A}$ & 99.9960 & 0.0019 & 0.0004 & 0.0006 & 0.0006 \\
$\mathrm{~B}$ & 99.9916 & 0.0063 & 0.0005 & 0.0006 & 0.0010 \\
$\mathrm{C}$ & 99.9785 & 0.0086 & 0.0011 & 0.0008 & 0.0110 \\
\hline
\end{tabular}

陽極の分類

$\begin{array}{ll}\text { A - No. } 1 \sim \text { No. } 3 & \text { L. } 13 \sim \text { L. } 35 \\ \text { B - No. } 4 \sim \text { No. } 6 & \text { No. } 10 \sim \text { No. } 12 \\ \text { C }- \text { No. } 7 \sim \text { No. } 9 & \end{array}$

(2) ダートの表面積は約 $183 \mathrm{~m}^{2}$ ，これに対して各陽極 からの総電流汢平均约 $5 \mathrm{~A}$, したがって平均電流密度は $0.027 \mathrm{~A} / \mathrm{m}^{2}$ である。13 個の亜鉊陽極の発生電流の時間 的変化を第 3 図に示寸。これは陽極からの発生電流を 1 日 1 回測定し，これをプロットして近似曲線としたもの であるが，実際汇は電流は潮の干満，風浪，気温等の諸 条件により1日のうちでも常に多少の変動があるようで ある。第 3 図において, 下段 No. 31 陽極の発生電流の 11月27日に打ける上昇は，当日この陽極を引上げ表面の 附羙物を除去したためと考えられる。

（3）対海水電位を飽和甘乘基準，真空管電位差計を用

* 本委員会 30 年 2 月, 月例会箂上発表

** 中川防触工業侏式会社 


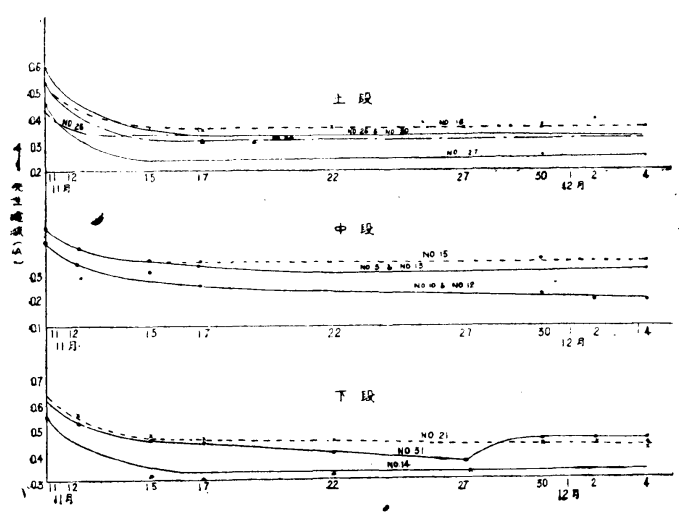

第3図 覀鉊陽極発生電流の変化

凡、て測定した結果はつぎのごとくである。

不通電時 - - $-0.58 \mathrm{~V} \sim-0,60 \mathrm{~V}$,

通電值後— $-0.74 \mathrm{~V}$,

48時間後—- $-0.92 \mathrm{~V} \sim-0.99 \mathrm{~V}$

電位分布は全域にわたってほぼ均一であった。

(4) ゲートに取付けた軟鋼試験片による防蝕試験結果 は第 2 表に示すごとくである。

第 2 表 試験片による防蝕試験結果

\begin{tabular}{|c|c|c|c|c|c|}
\hline & 試台 & $\begin{array}{c}\text { 噟色減量 } \\
\mathrm{mg}\end{array}$ & $\begin{array}{l}\text { 鹰蝕度 } \\
\mathrm{g} / \mathrm{m}^{2} / \mathrm{yr}\end{array}$ & $\mid \begin{array}{c}\text { 侵蝕度 } \\
\mathrm{mm} \times 10^{-8} / \mathrm{yr}\end{array}$ & $\begin{array}{c}\text { 防鳋率 } \\
\%\end{array}$ \\
\hline 渄防会 & No. & 446.1 & 1344.0 & 171.00 & 0 \\
\hline \multirow{3}{*}{ 段 } & 1 & $\cdots 1.6$ & 4.8 & 0.60 & 99.6 \\
\hline & 2 & 0.2 & 0.6 & 0.08 & 99.8 \\
\hline & 3 & 0.3 & 0.9 & 0.11 & 99.8 \\
\hline \multirow{3}{*}{ 中 } & 4 & 0 & 0 & 0 & 100.0 \\
\hline & 5 & 1.4 & 10.1 & 1.30 & 99.2 \\
\hline & 6 & 1.4 & 10.1 & 1.30 & 99.2 \\
\hline \multirow{3}{*}{ 段 } & 7 & 1.2 & 8.6 & 1.10 & 99.3 \\
\hline & 8 & 6.0 & 43.3 & 5.50 & 96.7 \\
\hline & 9 & 7.5 & 54.0 & 6.90 & 95.8 \\
\hline
\end{tabular}

催考 試片表面積 $50.7 \mathrm{~cm}^{2}$, 漫漬期闆 No. $1 \sim 3,573$ 時開, No. 4 9, 240 時間

このように極めてかずかな電流で良好な電位分布およ
び防蝕効果が得られたことは，このゲートに防蝕塗装が 施されてあったためで，塗装との併用は非常に有利であ ると考兄られる。

（5）使用した亜鉛陽極の消耗量を比較すると第 3 表の ごとくである。な怙平均電流は第 3 図より図積分によっ て求めたるのである。陽極の消耗量については現場試験 の関係上陽極の洗滌, 秤量等にあまりの厳密さは期待で

第 3 表 覀鉛の消耗量 23 日間

\begin{tabular}{|c|c|c|c|c|c|c|}
\hline 配紱 & $\begin{array}{l}\text { 陽 極 } \\
\text { No. }\end{array}$ & $\begin{array}{l}\text { 減 量 } \\
\text { kg }\end{array}$ & $\begin{array}{c}\text { 本均露流 } \\
\text { A }\end{array}$ & $\begin{array}{c}\text { 涓耗量 } \\
\mathrm{Kg} / \mathrm{A}-\mathrm{yr}\end{array}$ & $\begin{array}{l}\text { 発生曘気量 } \\
\text { A. Hr/kg }\end{array}$ & $\begin{array}{c}\text { 售触度 } \\
\mathrm{kg} / \mathrm{m}^{2} / \mathrm{yr}\end{array}$ \\
\hline \multirow{3}{*}{ 上 } & L-16 & 0.26 & 0.38 & 10.9 & 804 & 31.6 \\
\hline & L-24 & 0.29 & 0.33 & 13.9 & 630 & 35.2 \\
\hline & L-26 & 0.34 & 0.34 & 15.9 & 552 & 41.2 \\
\hline \multirow[t]{2}{*}{ 段 } & L-27 & 0.18 & 0.26 & 11.0 & 797 & 21.9 \\
\hline & L-30 & 0.26 & 0.36 & 11.5 & 762 & 31.6 \\
\hline \multirow{3}{*}{ 中 } & $\mathrm{A}-3$ & 0.19 & 0.33 & 9.15 & 958 & 27.3 \\
\hline & B-10 & 0.21 & 0.24 & 13.9 & 631 & 30.1 \\
\hline & B-12 & $0 . ? 2$ & 0.24 & 14.5 & 604 & 31.6 \\
\hline \multirow[t]{2}{*}{ 段 } & L-13 & 0.26 & 0.33 & 12.5 & 701 & 31.6 \\
\hline & L-15 & 0.30 & 0.35 & 13.6 & 643 & 36.4 \\
\hline \multirow[t]{2}{*}{ F } & L-14 & 0.32 & 0.35 & 14.5 & 605 & 38.9 \\
\hline & L-21 & 0.38 & 0.45 & 13.4 & 654 & 46.2 \\
\hline 度 & L-31 & 0.38 & 0.44 & 13.7 & 640 & 46.2 \\
\hline
\end{tabular}

きなかったが，その概略の数值は知ることができた。

\section{3. 結}

本試験の結果ゲートのような海水中の小規模鉄鋼施設 は，高純度の覀鉊陽極により極めて経済的に防蝕するこ とができることが判明した。この場合防蝕塗装と併用す ることは, 電流分布を改善し, 所要防蝕電流密度を減少 ししたがって陽極の寿命あるいは所要個数を減少するこ とができるのできわめて経済的である。陽極の消耗量は 理論值の 80 ～90\%を示し, 発生電流は通電後 5 〜日間 で安定し，その後はほぼ一定電流で経過する。低純度亚 鉊に見られるごとき発生電流の低下および表面に硬い被 膜の形成は見られなかった。

最後に本試験に際して雬々とご協力いただいた運輸省 港湾局，同京浜港工事々務所にたいして，また終始ご指 導をいただいた東京工業試験所重野隼太技官および日本 大学工学部山本洋一博士にたいして樑く感謝の意を表し ます。(30年3月 1 日受理) 